\title{
Lactarius mammosus and L. moseri n. sp.
}

\author{
HARRI HARMAJA
}

\begin{abstract}
HARMAJA, H. 1985: Lactarius mammosus and L. moseri n. sp. - Karstenia 25: 47-49.

The new agaric species Lactarius moseri Harmaja is described on the basis of Finnish material, and is also reported from Sweden. $L$. moseri is a close relative of $L$. vietus (Fr.: Fr.) Fr. In recent years, it has been claimed that $L$. mammosus Fr. is the correct name for the fungus which is here described as $L$. moseri. The author, however, suggests that $L$. mammosus is the correct name for $L$. fuscus Roll., this conclusion agreeing with the interpretation of many other mycologists. The nomenclature of $L$. mammosus is clarified; the walls of the cystidia and pseudocystidia of L. mammosus are reported to be amyloid, which is a unique character in the genus.
\end{abstract}

Harri Harmaja, Botanical Museum, University of Helsinki, Unioninkatu 44, SF-00170 Helsinki, Finland.

Lactarius moseri Harmaja, n. sp.

Lactarius moseri Harmaja ex M. Korhonen, Suomen rouskut 131. 1984, nom. inval. Fr.

Misapplied name: Lactarius mammosus s. Moser 1976, non

Lactarii vieti propinqua. Ab ea praecipue differt pileo umbrino plerumque umbonato, stipite longiore distincte clavato non nec sporis, cystidiis, habitatione leniter dissimilibus. Sporae 6.5-9.0 $\times 6.0-7.5 \mu \mathrm{m}$. Cheilocystidia fusiformes, elongato-fusiformes vel anguste ampullacea, $35-80 \times 5.0-8.0(-10.0) \mu \mathrm{m}$. Pseudocystidia 1.8-3.0 $\mathrm{\mu m}$ in diametro. Plerumque paludicola. - Typus: Finland, prov. Uusimaa, Vantaa, Viinikanmetsä, Mottisuo, Rismossen, fairly oligotrophic spruce-hardwood swamp with, e.g., Picea abies, Betula pubescens, Rubus chamaemorus and Sphagnum girgensohnii, Grid 27 ${ }^{\circ}$ E: 6691:385, 28.VIII.1982 Mauri Korhonen (H, holotype; IB, MICH, PRM, UPS, isotypes).

This new species is named in honour of the eminent mycologist, Prof. Meinhard Moser (Innsbruck, Austria). He was apparently the first to publish observations of the present species (Moser 1976, as $L$. mammosus Fr.).

L. moseri is closely related to L. vietus (Fr.: Fr.) Fr., differing in the fairly dark purple-tinged chocolate brown and mostly umbonate pileus, the longer and distinctly clavate stipe, the somewhat more elevated spore ornamentation and the narrower ecological amplitude, since the species usually grows in bogs and swamps and paludified woods ( $L$. vietus also occurs in less moist habitats). Several minor differences apparently exist as well, e.g., in L. moseri the spores tend to be slightly shorter and thus slightly broader in propotion to their length, and cystidia are slightly narrower.

L. moseri occurs from the beginning of August to the end of September in different kinds of oligotrophic peatland. Very infrequently, it has been collected in dry oligotrophic heath forest and in somewhat moist mesotrophic woodland. It is probably always associated with Betula pubescens. At present, L. moseri is known from several places scattered throughout Finland and from some localities in southern Sweden, occurring from the hemiboreal to the northern boreal zone. The species is much less frequent than $L$. vietus.

The first mycologist to pay attention to the present species may have been Prof. Emer. Risto Tuomikoski (Helsinki). He has not published his observations, but they can be seen on the labels of his specimens; he suspected that these represented an undescribed species. Mr. Tauno Ulvinen (Oulu, Finland) also noticed the existence of this fungus. Moser (1976) reported this species from southern Sweden, but did not consider it new, claiming that it represented the true L. mammosus of Fries. Below, under $L$. mammosus, I conclude that such an interpretation of L. mammosus is not acceptable.

A short illustrated description of $L$. moseri was published by Moser (1976, as L. mammosus). Korhonen (1984) also treats the species (as L. moseri, in Finnish), giving a good description and presenting both a colour photograph of the type specimen in situ and microscopic drawings.

Specimens examined

Finland. Varsinais-Suomi: Tenhola, 15.IX.1979 Korhonen, Tuomikoski \& Ulvinen (H). Uusimaa: Espoo, 26.VIII.1983 Kytövuori 83027 (H). Helsinki, 23.VIII.1951 Tuomikoski (H). Vantaa, 28.VIII.1982 Korhonen 4813 (type, H, IB, MICH, PRM, UPS); 15.IX.1984 Ahti 41815 (H). EteläHäme: Koski, 30.VIII.1977 Harmaja (H); 4.IX.1979 Harmaja et al. (H); 29.VIII.1984 Ahlholm \& Teittinen (H). Kärkölä, 31.VIII.1971 Tuomikoski (H). Lammi, 5.IX.1974 Tuomikoski(H); 28.VIII.1979 Korhonen \& Tuomikoski (H); 6.IX.1979 Korhonen 2901 \& Tuomikoski (H); 4.VIII.1984 


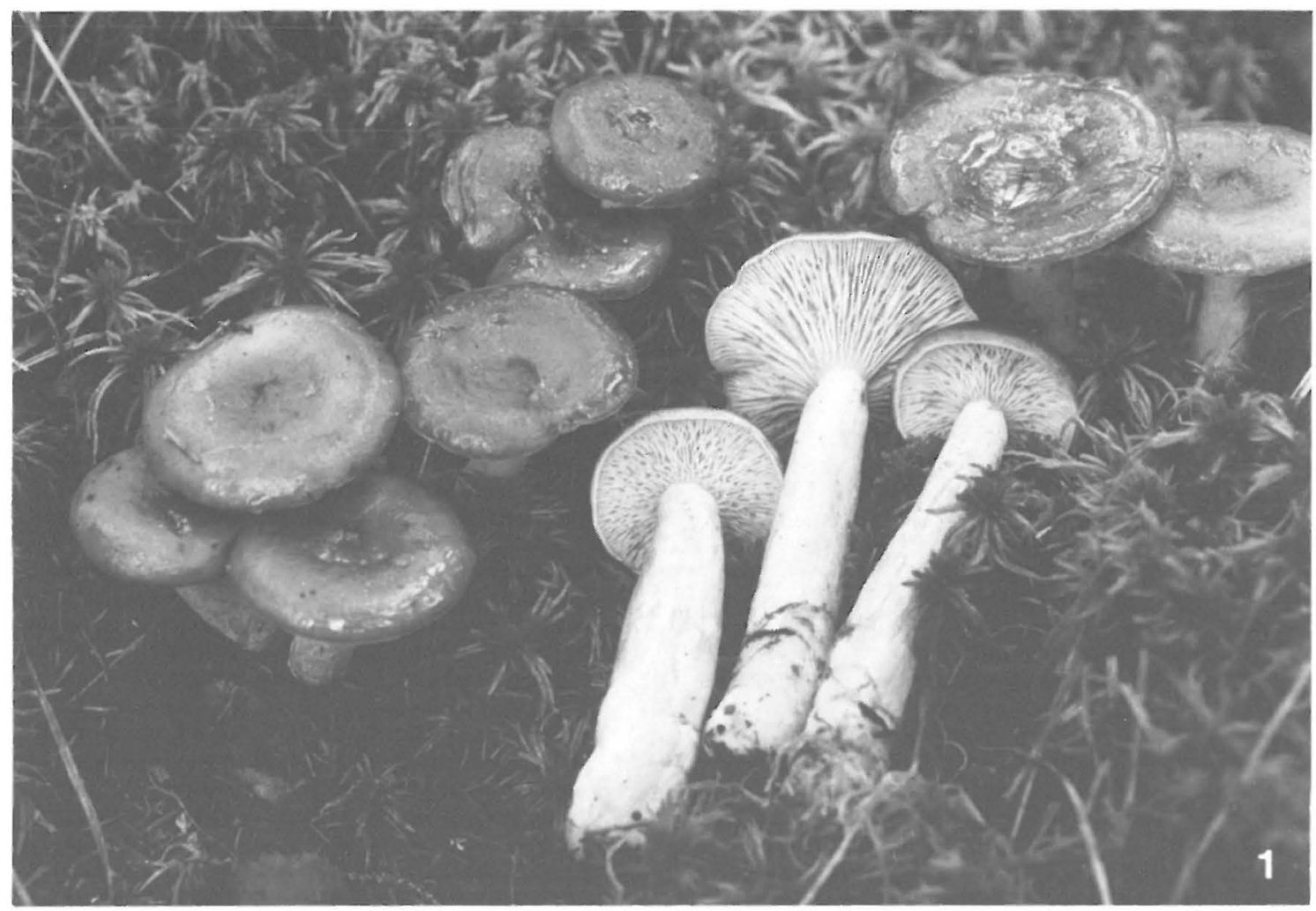

Fig.1. Lactarius moseri fresh in situ, about natural size (part of type). - Photo: Mauri Korhonen.

Harmaja (H); 31.VIII.1984 Heikkonen (H). Pohjois-Häme: Äänekoski, 23.VIII.1981 Harmaja (H). Oulun Pohjanmaa: Oulu, 5.IX.1980 Ulvinen (OULU); 18.VIII.1982 Ulvinen (OULU). Rovaniemi mlk. 11.VIII.1974 Ulvinen (OULU). Koillismaa: Kuusamo, 12.VIII.1975 Ulvinen (OULU). Inarin Lappi: Utsjoki, 20.VIII.1975 Ulvinen (OULU).

\section{Lactarius mammosus Fr.}

Agaricus mammosus Fr. ex Weinm., Hymeno- et GasteroMyc. Ross. 49. 1836, nom. illegit. (later homonym of Agaricus mammosus L. 1753 = Entoloma mammosum (L.) Hesler). - Lactarius mammosus Fr., Epicrisis 347. 1838. Type: Not designated.

Lactarius subumbonatus Lindgren 1845.

Lactarius fuscus Rolland 1899.

Lactarius hibbardiae ('Hibbardae') Peck 1908.

Lactarius confusus Lundell 1939.

It has been overlooked that Weinmann (1836) was the first to publish the description of the present species ('A. mammosus Fr. in lit.'). Apparently Fries told Weinmann in a letter that he intended to describe a new species with the epithet 'mammosus' in his 'Epicrisis', which was soon to appear. However, Weinmann still used the generic disposition under Agaricus and apparently himself made the description of $A$. mammosus, because its wording is different from that of Fries (1838). Technically, Fries published a new species, L. mammosus Fr., since Agaricus mammosus Fr. ex Weinm. is an illegitimate later homonym. However, it is important to note that the protologue of $A$. mammosus belongs to the protologue of Lactarius mammosus Fr. and that the latter species can also be typified with Weinmann's material, if extant. Weinmann's fungus seems to be the same species as that of Fries.

The name L. mammosus was not much used after Fries, and its meaning varied. The name later became firmly established through the Lactarius monograph of Neuhoff (1956). Moser (1976) lists authors and publications that accepted Neuhoff's interpretation, among others himself till 1970. However, Neuhoff (1956) and Moser (1976) are incorrect in stating that Tuomikoski (1953) was the first after Fries to use the name L. mammosus in the sense of Neuhoff. The name had already been used in this meaning by Konrad \& Maublanc (1924-1937) who list L. mammosus beside L. glyciosmus (Fr.: Fr.) Fr. and give L. fuscus as its synonym. Maire (1911) in fact shared this opinion, and the figure and description of $L$. mammosus in Bresadola (1928) almost certainly refer to that species.

Fairly general agreement had prevailed about the interpretation of L. mammosus until Moser (1976) presented his revised opinion: by this name Fries originally meant a close relative of L. vietus (Fr: Fr.) Fr. possessing a glabrous and viscid pileus, greying milk and a very faint odour, and growing in bogs and swamps. 
The protologue of L. mammosus (Fries 1838) fits fairly well, but not completely, with $L$. mammosus sensu Neuhoff (1956). Fries' concept of the species is consistent in all his publications and the descriptions are almost identical. The figure in the 'Icones' (Fries 1882) accords with the descriptions and is a good and unmistakable representation of $L$. mammosus sensu Neuhoff (1956). However, that figure does not formally belong to the protologue, which contains a reference to a figure published my Micheli (and another to a figure of Krombholz but without a definitive identification). The question of the identity of Lactarius mammosus Fr. can be finally settled only by typification, but because this is so complicated, it has not been done here. A neotypification is hardly possible, even if no Weinmann material exists, because of the reference to the existing figure of Micheli, which could not be studied in this connection. Six details in the protologue appear relevant in deciding whether it refers to L. mammosus sensu Neuhoff (1956) or L. mammosus sensu Moser (1976); the Latin words quoted here were extracted from Fries' description:

(1) Fries placed L. mammosus between $L$. helvus and L. glyciosmus, both belonging to a group with a very dry pileus ( $L$. vietus is in another group, which, according to Fries, contains viscid species).

(2) 'statura fere praeced.' (habit often as in the preceding species [L. helvus]).

(3) 'pileo... villo intricato griseo obtexto' (with a greyvillose pileus)

(4) 'lacte albo' (with white milk)

(5) 'inodorus' (odourless)

(6) 'In pinetis ad viarum latera' (in coniferous woods on roadsides)

Apart from (5), all the above points are very typical of $L$. mammosus sensu Neuhoff (1956), but exclude $L$. mammosus sensu Moser (1976), in particular the words in italics in point (3). In the protologue of $L$. vietus Fries describes the pileus as smooth and slightly viscid, and the milk as white at first then changing to greyish; these characters are also typical of $L$. mammosus sensu Moser (1976). Fries accordingly distinguished between a dry villose pileus and a smooth viscid pileus, and between persistently white milk and greying milk. Point (5) is the only one which fits well with Moser's fungus but less well with $L$. mammosus sensu Neuhoff (1956). However, it is wellknown that the typical pleasant odour of the latter fungus is weak at times and may be lacking in young or very fresh fruit bodies, and persistently odourless forms may even exist. Moreover, Fries did not always distinguish odours well; e.g., his description of the characteristic odour of L. helvus (Fr.) Fr. is inappropriate.

Fries had most probably found $L$. mammosus sensu Moser (1976), but included it in L. vietus.

The four later synonyms of $L$. mammosus are according to Neuhoff (1956). I have not examined their identity myself but their synonymy is generally accepted, especially in the case of $L$. fuscus and $L$. confusus.

Moser (1976) writes that the present species is 'associated with spruce'. Spruce may be a secondary host for the fungus, but it is the pine (Pinus) that is usually supposed to have an ectotrophic mycorrhiza with $L$. mammosus.

I found that the walls of the cheilocystidia, pleurocystidia and pseudocystidia are amyloid. The degree of amyloidity varies in different cystidia and specimens, the reaction generally being strongest in fully developed cystidia and in the apical parts of the cystidial cells. This character has been noted in several specimens and thus appears to be specific to $L$. mammosus. It is evidently absent from the other members of the genus Lactarius.

Acknowledgements. I am very grateful to Mr. Mauri Korhonen for valuable discussions on $L$. moseri and for permission to publish his photograph of the type of the species, and to Prof. Teuvo Ahti for improving the manuscript.

\section{References}

Bresadola, G. 1928: Iconographia mycologica 8. - Pls. 351-400. Mediolani.

Fries, E. 1838: Epicrisis systematis mycologici, seu synopsis hymenomycetum. - 610 pp. Upsaliae.

- 1882: Icones selectae Hymenomycetum nondum delineatorum 2: 7/8. - pp. 59-78, pls. $161-180$. Upsaliae.

Konrad, P. \& Maublanc, A. 1924-1937: Révision des Hyménomycètes de France et des pays limitrophes. 558 pp. Paris.

Korhonen, M. 1984: Suomen rouskut. -223 pp. Helsinki.

Maire, R. 1911: Notes critiques sur quelques champignons récoltés pendant la session de Grenoble-Annecy de la Société Mycologique de France (Septembre-Octobre 1910). - Bull. Soc. Mycol. France 27: 403-452, pls. $13-15$.

Moser, M. 1976: The problem of Lactarius mammosus Fr. - Kew Bull. 31: 529-532.

Neuhoff, W. 1956: Die Milchlinge (Lactarii). - In: Die Pilze Mitteleuropas 2b: $1-248$, pls. 1-18. Bad Heilbrunn.

Tuomikoski, R. 1953: Die Lactarius-Arten Finnlands. Karstenia 2: 9-25.

Weinmann, C.A. 1836: Hymeno- et Gastero-Mycetes hucusque in imperio Rossico observatos. - $676 \mathrm{pp}$. Petropoli. 